\title{
HYDROGEOLOGIC CONNECTIVITY OF TWO MAJOR SPRING ORIFICES: MAIN BARTON AND ELIZA SPRINGS TEXAS
}

\author{
Sarah J. Zappitello, PG \\ City of Austin Watershed Protection \\ 505 Barton Springs $R d$. \\ Austin,TX, 78704,United States,saj.zappitello@austintexas.gov
}

David A. Johns, PG

City of Austin Watershed Protection

505 Barton Springs Rd.

Austin, TX, 78704,United States, david.johns@austintexas.gov

Lindsey Sydow, PG

City of Austin Watershed Protection

505 Barton Springs Rd.

Austin, TX, 78704, United States, lindsey.sydow@austintexas.gov

\begin{abstract}
The subsurface hydrogeologic connection between Main Barton Spring and Eliza Spring has long been known and assumed due to proximity, geologic structure, presence of unique species, water chemistry, and groundwater tracing studies. Fifteen-minute water quality monitoring data from both springs paired with three accidental releases of sediment to the aquifer and resulting changes in spring turbidity provided new information at a higher resolution than previously available. The turbidity response consistently arrived at Eliza Spring 15 minutes after the response at Main Barton Spring; however, our sampling interval was 15 minutes, so the travel time between springs may have been slightly more or less than 15 minutes. The duration of the turbidity pulse was similar at each spring. Sediment is not a traditional groundwater tracing tool, but this event provided a unique opportunity to compare responses at the two springs. The 23-year history of aquifer dye tracing in the Barton Springs Segment of the Edwards Aquifer provides a robust context to evaluate the dynamics between individual springs. Main Barton Spring feeds a popular and historic municipal pool inhabited by two species of endangered salamanders, the Barton Springs Salamander and the Austin Blind Salamander. These salamanders are also observed, typically in greater abundance, at Eliza Spring. Understanding the aquifer dynamics between the two springs is important for management of the endangered species habitat.
\end{abstract}

\section{Introduction}

The hydrologic connection between Main Barton Spring (within Barton Springs pool) and Eliza Spring (23 m (75 ft) north of the pool) has long been assumed due to proximity, geologic structure, presence of unique species, water chemistry, geochemical storm responses, and groundwater tracing studies; however, the hydrogeologic response between the two springs has not been analyzed and documented in the literature. Comparing and contrasting physical and chemical water quality parameters during responses to natural and artificial events, such as storms and spills, reveals information about the sources and pathways of water between the two springs.

Main Barton Spring and Eliza Spring are two of four major orifices of the Barton Springs complex (Figure 1). Barton Springs is the biggest spring in Austin, Texas, USA, and the major outlet of the Barton Springs Segment of the Edwards Aquifer along with Cold Spring (Figure 2). Barton Springs and the Edwards Aquifer are formed in the Cretaceous-age Georgetown Limestone and underlying Person and Kainer Formations of the Edwards Group of central Texas. Main Barton Spring and Eliza Spring are located along the same geologic fault, which is a likely conduit for groundwater flow. Preferential dissolution along faults often creates pathways for high velocity flow through karst aquifers. Each of the four spring orifices provides habitat for two species of endangered salamanders, the Barton Springs Salamander and the Austin Blind Salamander, though Eliza and 


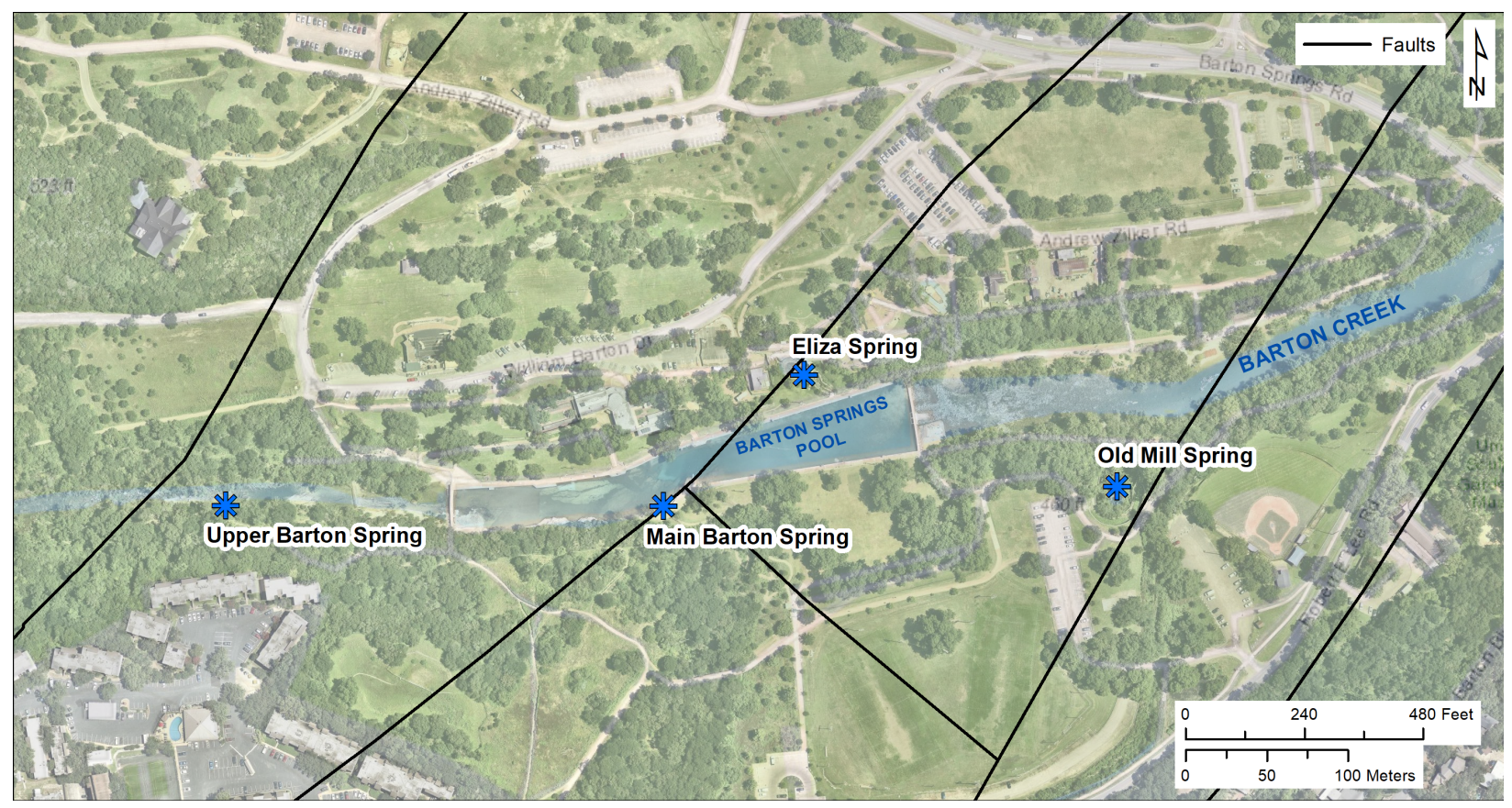

Figure 1. The four major springs that comprise the Barton Springs complex and mapped locations of geologic faults.

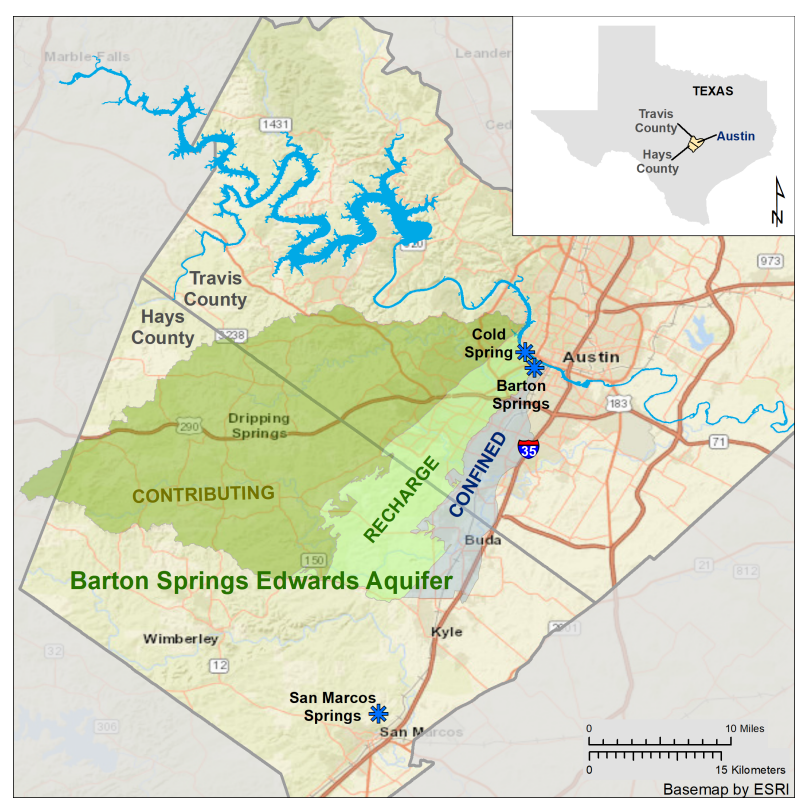

Figure 2. Location of Barton Springs and the Barton Springs Segment of the Edwards Aquifer in Austin, Texas.

Main Barton contain the first and second most abundant populations respectively.

Groundwater dye tracing has been conducted in the Barton Springs Segment of the Edwards Aquifer for more than 20 years (Hauwert et al 2004, Hunt et al 2005, Smith et al 2006, Smith et al 2012, Hauwert 2012, Hunt et al 2013, Smith et al 2017, Zappitello and Johns 2018). During that time period three groundwater basins (Figure 3) have been defined which contribute to different portions of the Barton Springs complex and Cold Springs (Hauwert et al 2004). Main Barton and Eliza have been documented to discharge water from the same groundwater basin. Tracing samples have been collected from Eliza Spring at a maximum resolution of once a day and at Main Barton Spring at a maximum resolution of once an hour, so a fine-scale comparison of response times at the two springs was not available.

A long history of physical and chemical water quality data is also available for both springs (Turner 2000, Herrington et al 2005, Herrington and Hiers 2010, Mahler et al 2011, Porras 2014, Porras 2016). Continuous measurement of basic physical and chemical water quality parameters has occurred using deployable water quality sondes intermittently at Eliza since 1996, intermittently at Main Barton from 1993-2007, and continuously at Main Barton since 2007. The water chemistry at both springs has historically been similar, and the data from Main Barton is often used as a proxy for the conditions at Eliza. Water quality parameters are typically measured at 15-minute intervals and include turbidity (a measure- 


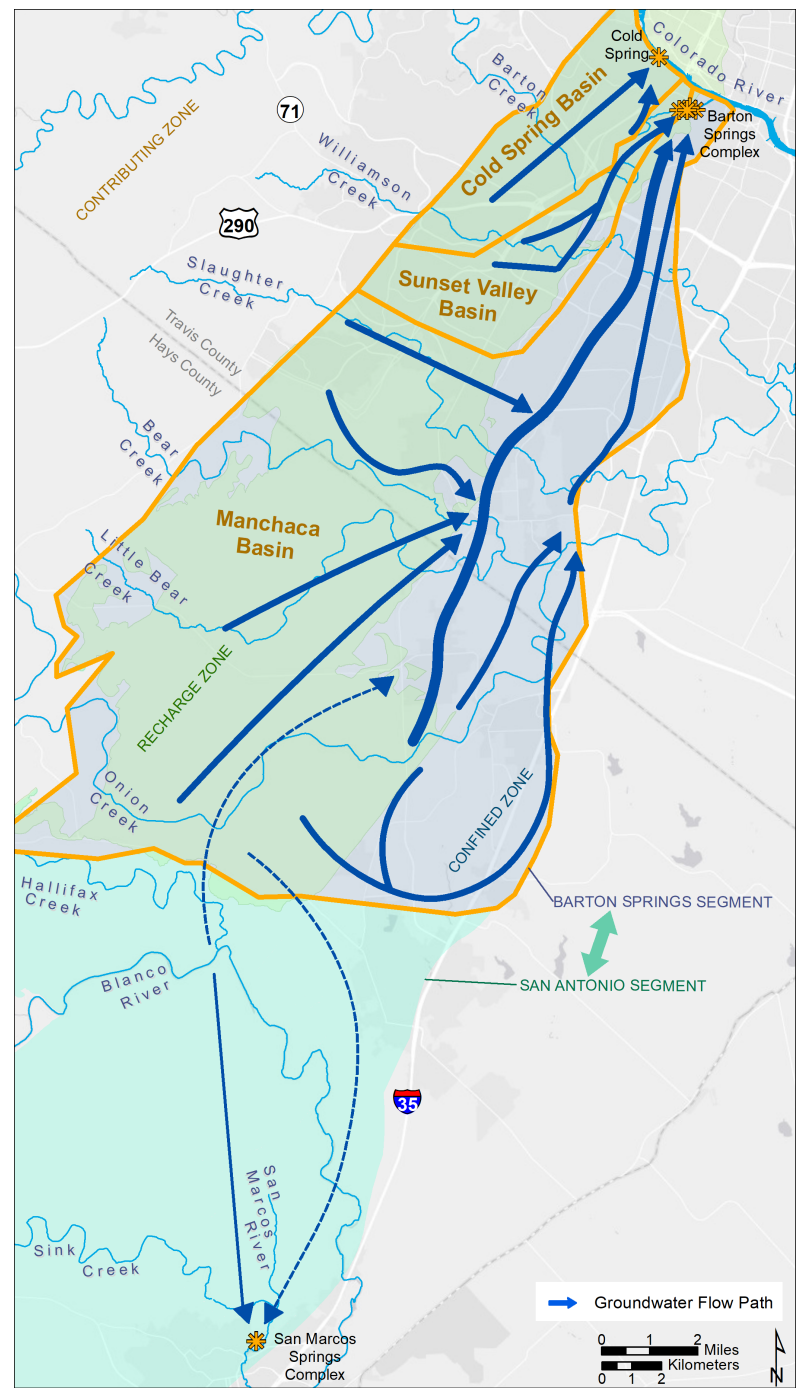

Figure 3. Groundwater basins and flowpaths within the Barton Springs Segment of the Edwards Aquifer, from Zappitello et al (2019). Adapted from (Hauwert et al 2004, Hunt et al 2005, Smith et al 2006, Hauwert 2009, Smith et al 2012, Hauwert 2012, Hunt et al 2013, Zappitello and Johns 2018).

ment of suspended sediment in the water) and specific conductance (a measurement related to the dissolved minerals in the water). Specific conductance is used to geochemically link storm response from recharging watersheds to karst springs, since the recharging storm water is "fresher" with a lower specific conductance than the stored aquifer water that contains higher levels of dissolved minerals due to longer contact with the host rock. The storm response manifests as a trough in the measurement of specific conductance.
The current analysis takes advantage of an accidental release of sediment through the aquifer which reached both springs and was measured by water quality equipment. On 18-20 December 2018, three separate sediment plumes arrived at Main Barton Spring and Eliza Spring accompanied by high turbidity measurements. On 18 December 2018, a brownish muddy discharge at Barton Springs pool was caused when a void was encountered during drilling for a geothermal heat pump well (Sydow et al 2019). The next day during grouting of the borehole, additional material was transported to the springs and turned the pool a milky white color. The third day drilling at an adjacent well encountered another void, and a smaller plume of brownish sediment appeared at Barton Springs pool. The differences at each spring in sediment release response times are compared to the differences in geochemical storm response times.

\section{Methods}

Turbidity and specific conductance are measured every 15 minutes by sensors on a water quality sonde at each of the two springs: Main Barton and Eliza. The water quality sonde at Main Barton Spring is maintained and operated by the USGS, and the water quality sonde at Eliza Spring is maintained and operated by the City of Austin (COA) Watershed Protection Department (WPD). Data quality is controlled by a combination of regular equipment calibration and data review by the respective agencies.

The sondes at Main Barton Spring and Eliza Spring use slightly different turbidity sensor designs, as indicated by the units of measurement. The sensors are similar in that they both measure scattered light at a 90-degree angle to the incident light beam, but they use different wavelengths of light to make the measurement (Anderson 2005). The turbidity sensor at Main Barton Spring uses an infrared or monochrome light with a wavelength of 780-900 nm measured in Formazin Nephelometric Units (FNU), while the turbidity sensor at Eliza Spring uses a white or broadband light with a wavelength of 400-680 $\mathrm{nm}$ measured in Nephelometric Turbidity Units (NTU). The sensor used at Eliza Spring is an OTT Hydromet brand self-cleaning sensor. It is calibrated approximately once a month following standard procedures outlined by the manufacturer (OTT Hydromet US, video posted 2011a). The sensor used at Eliza Spring is set to the Central Time Zone (CT) Network Time Protocol (NTP) 
standard every month during the routine calibration procedure. The sensor used at Main Barton Spring is a YSI brand self-cleaning sensor 6136. It is calibrated following USGS standard procedures (Wagner et al 2006). The sensor clock is set two to three minutes ahead of either iPhone standard time from a cellular network tower or a USGS networked computer on Central Standard Time (CST). The different sensor measurements are similar but not precisely equivalent in magnitude for environmental samples; however, the timing of the peak and duration of the measurements are valid parameters for comparison within the sampling period of 15-minute intervals.

Specific conductance is measured in units of microSiemens per centimeter (uS/cm). At Eliza Spring specific conductance is measured using an OTT Hydromet Hydrolab conductivity sensor. This sensor uses four graphite electrodes in an open cell design. It is calibrated approximately once a month following standard procedures outlined by the manufacturer (OTT Hydromet, video posted 2011b). At Main Barton Spring specific conductance is measured using a YSI conductivity sensor. This sensor uses four pure-nickel electrodes. It is calibrated following USGS standard procedures (Wagner et al 2006). Measurements from these different brands of sensors are assumed to be comparable.

\section{Results}

The initial response and peak measurements of turbidity serve as indicators of the arrival of the pulse of sediment (Table 1, Figure 4). The peak turbidity was measured at Eliza Spring 15 minutes after the peak turbidity measurement at Main Barton Spring for each pulse of sedi- ment (Table 1, Figure 5, Figure 6, Figure 7). The initial responses occurred at the same time in both springs for the first pulse, although at a much lower magnitude at Eliza than at Main Barton (Figure 5), and 15 minutes later at Eliza than at Main Barton for the second and third pulses of sediment (Figure 6, Figure 7). Peak turbidity is much greater than that produced by most rain events and the sharply defined turbidity curve is markedly different as well; for an example of turbidity produced by a rain event please see Sydow et al 2019.

The distance between the drilling site and the springs is approximately 1,250 meters $(4,100 \mathrm{ft})$, and the potential velocities ranged from 315 to $415 \mathrm{~m} /$ hour (1030 to 1360 $\mathrm{ft} / \mathrm{hr}$ ) as estimated by the timing of events at the well sites and documented impacts at the springs (Sydow et al 2019). At these velocities, water would be able to travel

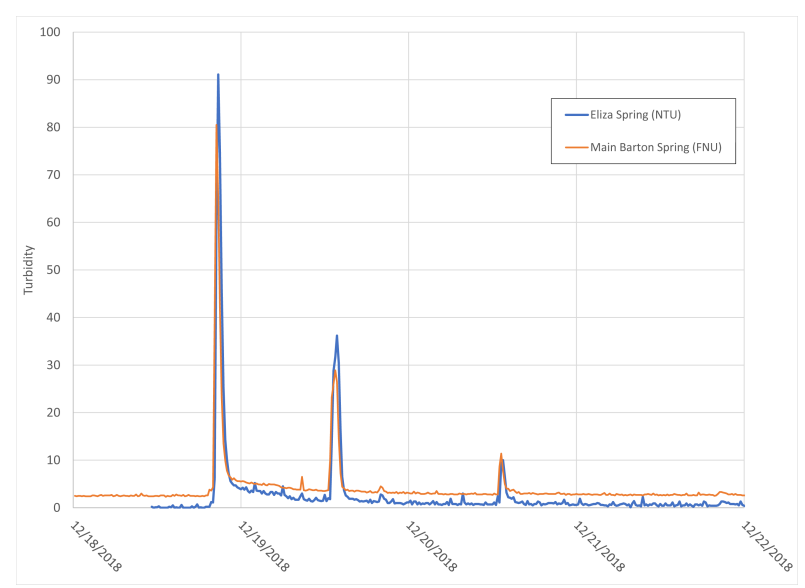

Figure 4. Graph of turbidity measured every 15 minutes at Main Barton Spring and Eliza Spring showing all three pulses of sediment.

\begin{tabular}{|l|l|l|l|l|l|l|}
\hline \multirow{2}{*}{ Date } & \multicolumn{2}{|l|}{ Eliza Spring } & \multicolumn{2}{l|}{ Main Barton Spring } \\
\cline { 2 - 7 } & $\begin{array}{l}\text { Initial } \\
\text { Response } \\
\text { Time }\end{array}$ & Peak Time & $\begin{array}{l}\text { Peak } \\
\text { Turbidity } \\
\text { (NTU) }\end{array}$ & $\begin{array}{l}\text { Initial } \\
\text { Response } \\
\text { Time }\end{array}$ & Peak Time & $\begin{array}{l}\text { Peak } \\
\text { Turbidity } \\
\text { (FNU) }\end{array}$ \\
\hline $12 / 18 / 2018$ & $20: 15$ & $20: 45$ & 91.1 & $20: 15$ & $20: 30$ & 80.5 \\
\hline $12 / 19 / 2018$ & $13: 00$ & $13: 45$ & 36.2 & $12: 45$ & $13: 30$ & 28.9 \\
\hline $12 / 20 / 2018$ & $13: 15$ & $13: 30$ & 10.0 & $13: 00$ & $13: 15$ & 11.4 \\
\hline
\end{tabular}

Table 1. Magnitude and time of turbidity peak at Main Barton Spring and Eliza Spring. 


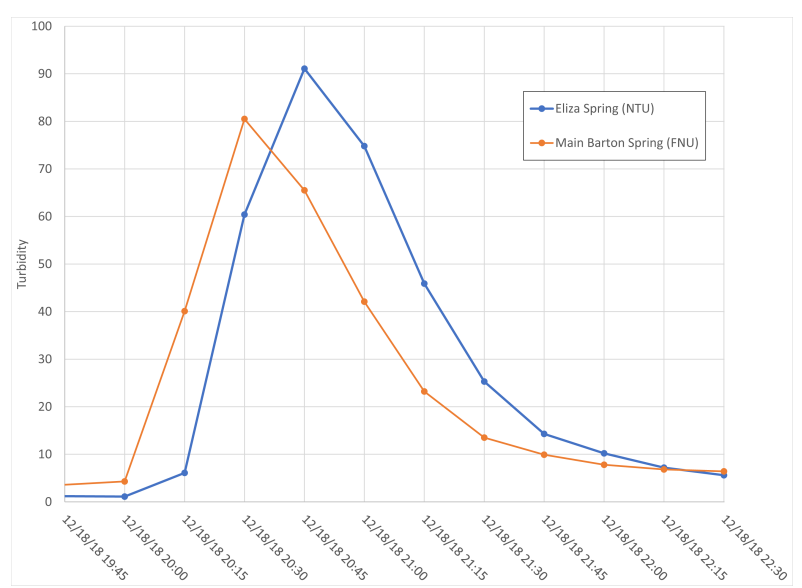

Figure 5. Pulse one on the evening of 12/18/2018: graph of turbidity measured every 15 minutes at Main Barton Spring and Eliza Spring.

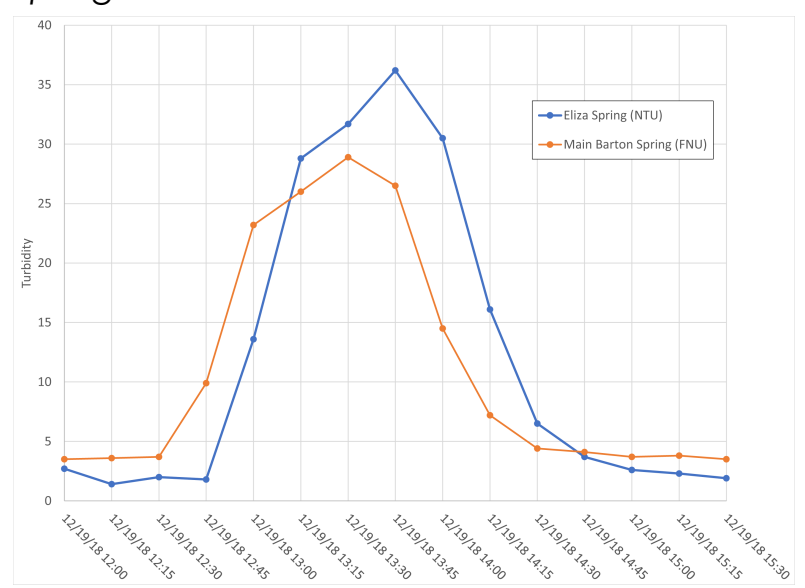

Figure 6. Pulse two on the afternoon of 12/19/2018: graph of turbidity measured every 15 minutes at Main Barton Spring and Eliza Spring.

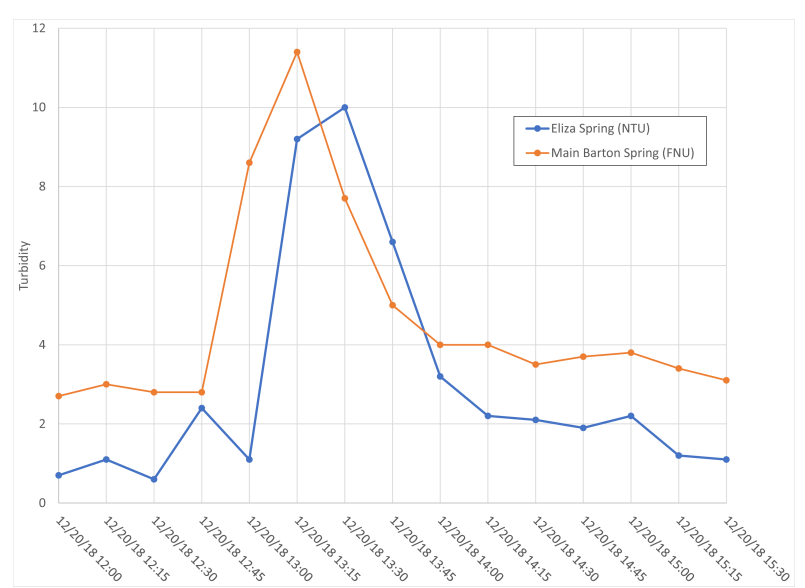

Figure 7. Pulse three on the afternoon of 12/20/2018: graph of turbidity measured every 15 minutes at Main Barton Spring and Eliza Spring.
79 to $104 \mathrm{~m}$ (260 to $340 \mathrm{ft}$ ) in 15 minutes. Eliza Spring is $104 \mathrm{~m}$ (340 ft) away from Main Barton Spring.

The response of each spring to storm events is another indication of the hydrologic connection between the two springs. The storm response on 10 September 2018 as captured by the troughs in specific conductance had a lag time between the two springs ranging from 30 minutes to 1.25 hours (Figure 8 ). The September storm fell over the watersheds of Williamson Creek, Onion Creek, and intervening creeks (Figure 9) with two separate peaks in rain fall. The multiple troughs in specific conductance are likely due to the two storm peaks and recharging water from the different creeks across the recharge zone. In July 2018 the difference in the response time was 1.5 hours for each of two separate storms (Figure 10). The July storms were more focused over the watershed of Williamson Creek (Figure 11). Over the recharge zone, Williamson Creek ranges from 5.8 to $9.1 \mathrm{~km} \mathrm{(3.5} \mathrm{-} 5.7$ mi) away from Barton Springs, and Onion Creek ranges from 22.5 to $30 \mathrm{~km}(14.0-18.7 \mathrm{mi})$ away from Barton Springs (Figure 3). Other recharging creeks include Barton Creek, Slaughter Creek, Bear Creek, Little Bear Creek, and sometimes the Blanco River (during dryer low-flow conditions, Smith et al 2012).

\section{Discussion}

Comparing the timing and duration of the sediment plume at the two springs provides insight into the relationship between the springs. The highest turbidity value consistently arrived at Eliza Spring 15 minutes after the highest value at Main Barton Spring; however, our sampling interval was 15 minutes, so the time delay may be between 0-44 min. This indicates that anything traveling in the water may get to Eliza Spring at the same time or slightly later than Main Barton Spring and the pool. Since the aquifer flowpaths are generally south to north, and Eliza is $340 \mathrm{ft}$ northeast of Main Barton along the fault, it seems logical for the water to arrive at Main Barton Spring first. This also indicates that both springs are fed by at least one common conduit. The duration of the pulse of material was similar at each spring, about 2 hours for the first and second pulses and one hour and 15 minutes for the third pulse, so the water source containing the sediment affected each spring for a similar amount of time. 


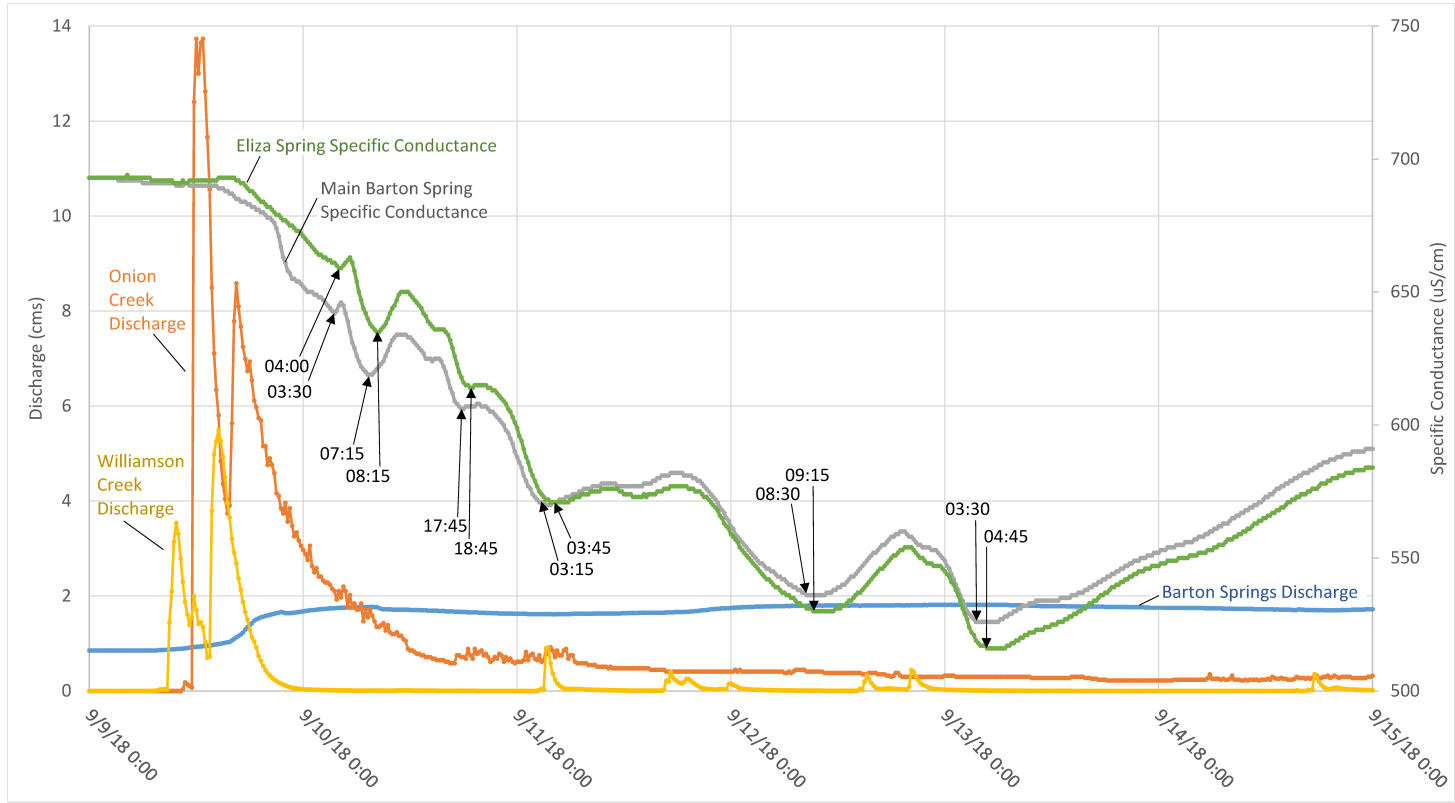

Figure 8. September 2018 geochemical storm response at Eliza Spring and Main Barton Spring as characterized by troughs in specific conductance.

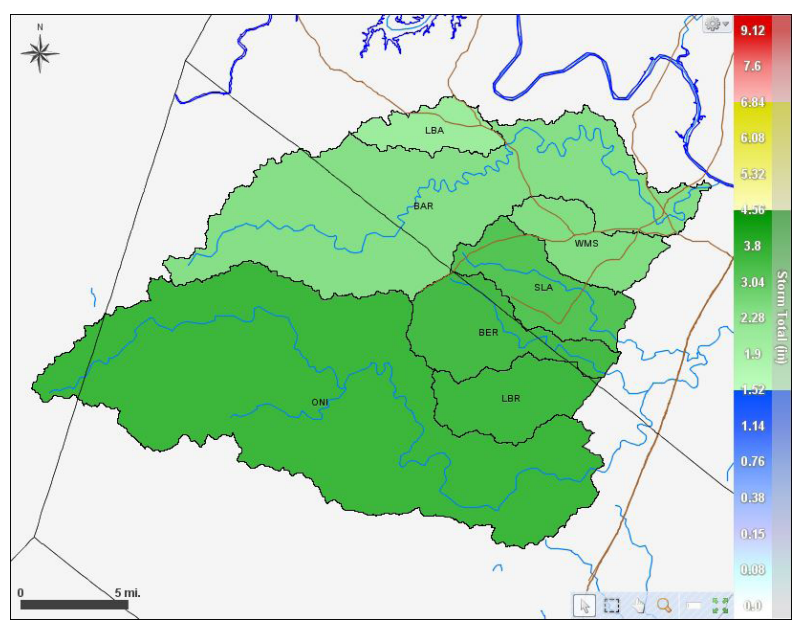

Figure 9. 9 September 2018 rainfall totals for watersheds over the contributing and recharge zones of the Barton Springs Segment of the Edwards Aquifer. ONI = Onion Creek, WMS = Williamson Creek.

The sediment and turbidity pulses provide valuable data for comparing Main Barton Spring with Eliza Spring in the context of past groundwater tracing studies. Past studies using nontoxic artificial tracers have identified similar water sources (as outlined in the Manchaca groundwater basin) contributing to both springs (Hauwert 2004); however, the resolution of sampling during past studies was at most once a day at Eliza Spring and once an hour at Main Barton Spring. Examining arrival times and transport dynamics of the sediment that arrived at the springs in December required no additional or special sampling since the 15-minute water quality sampling was already ongoing and included turbidity. Sediment is not a traditional groundwater tracing tool; however, this event provided an opportunity to compare responses to an acting tracer at the two springs at the higher resolution 15-minute timescale for the first time.

Eliza Spring is $104 \mathrm{~m}$ (340 ft) away from Main Barton Spring, so water moving between the two springs in 15 minutes would be traveling at approximately $415 \mathrm{~m} /$ hour (1360 ft/hour). Velocities of groundwater movement measured during previous groundwater tracing experiments range from 11 to $488 \mathrm{~m} /$ hour (35 to $1600 \mathrm{ft} /$ hour) (Johnson et al 2012, Smith et al 2006). The speed of groundwater movement within the Barton Springs Segment of the Edwards Aquifer varies due to aquifer levels and the overall amount of water in the aquifer. The discharge at Barton Springs as measured by the USGS is frequently used as a relative scale for the aquifer level. Barton Springs discharge on 18-20 December 2018 was 2.8 cubic meters/second (cms) (100 cubic feet per second (cfs)), which was relatively high; the median dis- 


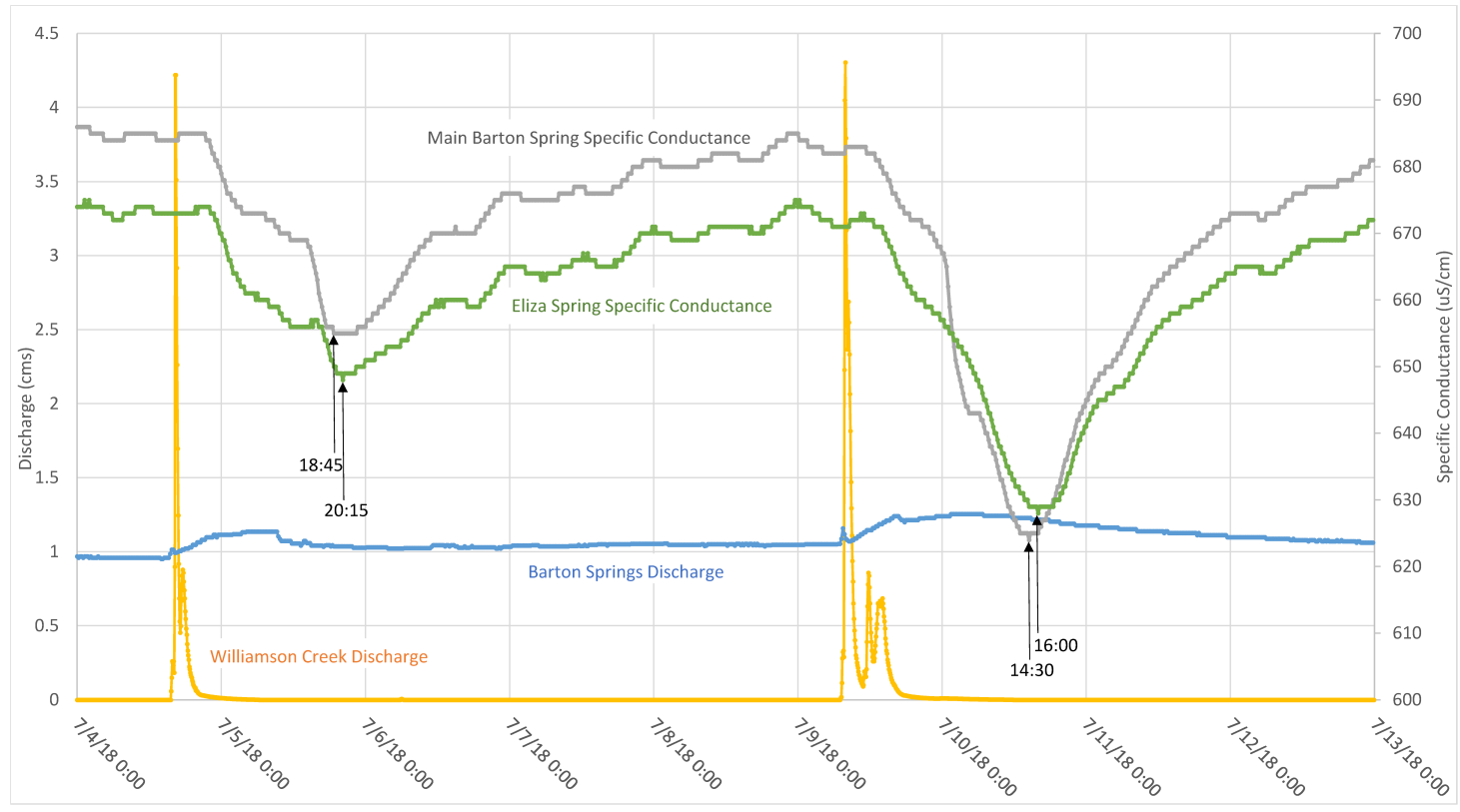

Figure 10. July 2018 geochemical storm response at Eliza Spring and Main Barton Spring as characterized by troughs in specific conductance.

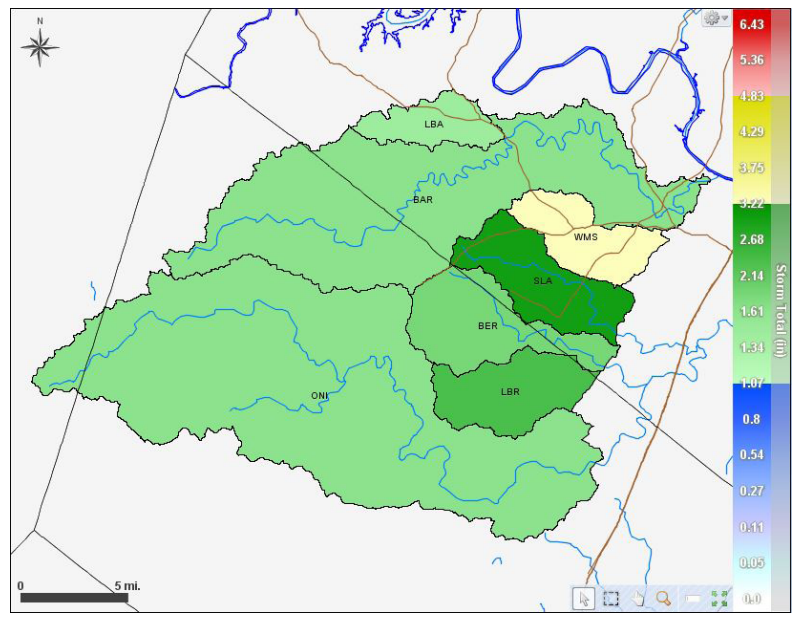

Figure 11. 4-9 July 2018 rainfall totals for watersheds over the contributing and recharge zones of the Barton Springs Segment of the Edwards Aquifer. WMS = Williamson Creek.

charge for that time of year is about $1.6 \mathrm{cms}(56 \mathrm{cfs})$. Groundwater tracing from one site on Onion Creek has demonstrated a range of velocities under differing groundwater conditions: ranging from $54 \mathrm{~m} /$ hour (178 $\mathrm{ft} /$ hour) in August 2000 when Barton Springs discharge

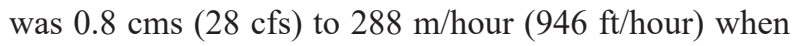

Barton Springs discharge was $2.4 \mathrm{cms}$ ( $86 \mathrm{cfs}$ ) (Hauwert et al 2004, Zappitello and Johns 2018). A velocity of water moving between the two springs of approximately $415 \mathrm{~m} /$ hour (1360 ft/hour) is plausible and is at the upper end of the velocities estimated by the timing of the geotechnical drilling and arrival of sediment at Barton Springs pool. At $315-415 \mathrm{~m} /$ hour $(1030-1360 \mathrm{ft} / \mathrm{hr})$, the water would take 15 to 20 minutes to travel the $104 \mathrm{~m}$ $(340 \mathrm{ft})$ between the springs.

The turbidity response provides insight into the aquifer dynamics between Eliza Spring and Main Barton Spring during baseflow conditions. The timing and magnitude of storm responses at the two springs provides insight into the aquifer dynamics during time periods when large pulses of water are added to the system. The response at Eliza Spring consistently mirrors the response at Main Barton Spring with a slight delay. The delay in the storm response varied between 30 minutes and 1.5 hours for storms in July and September 2018. The variation in the time delay may be due to the distances that the water travels underground combined with the speed at which the water is flowing through the aquifer during different conditions. The highest volume and speed of water flow through the karstic Barton Springs segment of the Edwards Aquifer occurs in caves and conduits, so variation 
in the time delay may also be due to different conduits traveled by at least some stormwater as compared to the single conduit intercepted during the well drilling.

Since the water quality measurements at Main Barton Spring are posted hourly to the internet, it is a valuable time-sensitive indicator of conditions both at Barton Springs pool and at Eliza Spring. Knowing that Eliza Spring responds to substances being transported through the aquifer within +/- 15 minutes of Main Barton Spring at the pool is important for the management of this spring system. The Barton Springs complex is actively managed as habitat for two species of endangered salamanders, the Barton Springs Salamander and the Austin Blind Salamander, with Eliza Spring and Main Barton Spring as the most populated springs within the complex. The proximity of these two springs along with the aquifer-dwelling nature of the salamanders has prompted speculation about the nature of the subterranean connection between the two springs. Based on these results, water quality measurements from Main Barton Spring can continue to be used as a proxy for water quality and habitat concerns at Eliza Spring. Water entering the aquifer may arrive slightly sooner at Main Barton than at Eliza, and the lead time may vary depending on aquifer conditions, distance from the water source to the springs, and whether the water follows a conduit flowpath.

\section{Recommendations}

To find out exactly how much longer it takes groundwater to arrive at Eliza Spring than Main Barton Spring, additional sampling at smaller time intervals such as one-minute or five-minute intervals would be required. Evaluating response times at shorter time intervals would require precise synchronization of equipment clocks at both springs. Additional physicochemical analyses, for example applying statistical methods to characterize water chemistry responses to storms, are planned to evaluate similarities and differences between Eliza Spring and Main Barton Spring.

\section{Acknowledgements}

Many thanks to Radmon Rice and Scott Hiers of the Geologic Drainage Systems team at the City of Austin Watershed Protection Department for their assistance and support on this project. This manuscript benefitted from review by two anonymous reviewers.

\section{References}

Anderson, C.W. 2005. Turbidity (ver. 2.1): U.S.

Geological Survey Techniques of Water-Resources Investigations, book 9, chap. A6., sec. 6.7, September 2005, accessed 6 March 2019, from http://pubs.water.usgs.gov/twri9A6/.

Hauwert N, Johns D, Aley T, Sansom J. 2004. Groundwater Tracing Study of the Barton Springs Segment of the Edwards Aquifer, Southern Travis and Northern Hays Counties, Texas: Report by the Barton Springs/Edwards Aquifer Conservation District and City of Austin Watershed Protection and Development Review Department. 110 p. and appendices.

Hauwert N. 2009. Groundwater Flow and Recharge Within the Barton Springs Segment of the Edwards Aquifer, Southern Travis and Northern Hays Counties, Texas. PhD Dissertation, University of Texas at Austin. 316 p.

Hauwert N. 2012. Dye Trace Simulation of an Accidental Spill, Phase 10: State Highway 45

Southwest and MoPac South into the Barton Springs Segment of the Edwards Aquifer, Travis County, Texas. City of Austin, Watershed Protection Department, Short Report SR-13-01.

Herrington C, Hiers S, Johns D. 2005. Update of Barton Springs Temporal Trend Analysis-2005. City of Austin, Watershed Protection Department, Short Report SR-05-09.

Herrington C, Hiers S. 2010. Temporal Trend Analysis of Long Term Monitoring Data at Karst Springs, 2009. City of Austin, Watershed Protection Department, Short Report SR-10-06.

Hunt B, Smith B, Campbell S, Beery J, Hauwert N, Johns D. 2005. Dye tracing recharge features under high-flow conditions, Onion Creek, Barton Springs Segment of the Edwards Aquifer, Hays County, Texas. Austin Geologic Society Bulletin, V1: 70-86.

Hunt B, Smith B, Adams M, Hiers S, Brown N. 2013. Cover-Collapse Sinkhole Development in the Cretaceous Edwards Limestone, Central Texas. Proceedings of the 13th Multidisciplinary Sinkhole Conference on Sinkholes and Engineering and Environmental Impacts of Karst, Carlsbad New Mexico, May 2013, p. 89-102. 
Johnson S, Schindel G, Veni G, Hauwert N, Hunt B, Smith B, Gary M. 2012. Tracing Groundwater Flowpaths in the Vicinity of San Marcos Springs, Texas. Edwards Aquifer Authority, Report No. 12-01. $145 \mathrm{p}$.

Mahler B, Musgrove M, Sample T, Wong C. 2011. Recent (2008-2010) Water Quality in the Barton Springs Segment of the Edwards Aquifer and Its Contributing Zone, Central Texas, with Emphasis on Factor Affecting Nutrients and Bacteria. USGS Scientific Investigation Report 2011-5139.

OTT Hydromet US. 2011a. Video demonstrating standard calibration procedures.

Available at https://www.youtube.com/ watch?v=vELLTHHDm7U. Posted 26 July 2011. Accessed 20 March 2018.

OTT Hydromet. 2011b. Video demonstrating standard calibration procedures. Available at https:/www. youtube.com/watch?v=bgiFt3kleEE. Posted 10 October 2011. Accessed 20 March 2018.

Porras A. 2014. Updated Analysis of Dissolved Oxygen Concentrations at Barton Springs. City of Austin, Watershed Protection Department, Short Report SR-14-11.

Porras A. 2016. Analysis of Water Quality Trends at Barton Springs and surrounding springs in Austin, TX (1995-2015) and an Alternative Framework for Future Analysis. City of Austin, Watershed Protection Department, Short Report SR-16-04.

Smith B, Hunt B, Beery J. 2006. Summary of 2005 Groundwater Dye Tracing, Barton Springs Segment of the Edwards Aquifer, Hays and Travis Counties, Central Texas. BSEACD Report of Investigations 05012006. $31 \mathrm{p}$.

Smith B, Hunt B, Johnson S. 2012. Revisiting the Hydrologic Divide Between the San Antonio and Barton Springs Segments of the Edwards Aquifer: Insights from Recent Studies. Gulf Coast Association of Geological Societies Journal, V1: 55-68.

Smith B, Hunt B, Camp J. 2017. 30 Years of Aquifer Science. BSEACD Fact Sheet 0817. 8 p.

Sydow L, Johns D, Zappitello S, Maurer T. 2019 (in review). Environmental Forensic Investigation of Mystery Sediment Plumes at Barton Springs,
Texas. Paper in progress for Proceedings of the Conference on Sinkholes and the Engineering and Environmental Impacts of Karst 2020.

Turner M. 2000. Update of Barton Springs Water Quality Data Analysis-Austin, Texas. City of Austin, Watershed Protection Department, Short Report SR-00-03.

Wagner RJ, Boulger RW Jr, Oblinger CJ, Smith BA. 2006. Guidelines and standard procedures for continuous water-quality monitors - Station operation, record computation, and data reporting: U.S. Geological Survey Techniques and Methods 1-D3. 51 p. +8 attachments.

Zappitello S, Johns D. 2018. 2017 Groundwater Tracing in the Barton Springs Edwards Aquifer: Onion Creek and Little Bear Creek. City of Austin, Watershed Protection Department, Short Report SR-18-10. 29 p.

Zappitello S, Johns D, Hunt B. 2019. Summary of Groundwater Tracing in the Barton Springs Edwards Aquifer from 1996 to 2017. City of Austin, Watershed Protection Department, Data Report. 30 p. 